CLINICAL STUDY

\title{
Growth-restricted preterm newborns are predisposed to functional adrenal hyperandrogenism in adult life
}

\author{
Christiaan L Meuwese ${ }^{1,2}$, Anne M Euser ${ }^{2}$, Bart E Ballieux ${ }^{3}$, Huib A van Vliet ${ }^{4}$, Martijn J J Finken ${ }^{1,5}$, \\ Frans J Walther ${ }^{1}$, Friedo W Dekker ${ }^{2}$ and Jan $\mathrm{M} \mathrm{Wit}^{1}$ \\ ${ }^{1}$ Department of Pediatrics, ${ }^{2}$ Department of Clinical Epidemiology, ${ }^{3}$ Chemical Laboratory and ${ }^{4}$ Department of Reproductive Medicine, Leiden University \\ Medical Center, PO Box 9600, 2300 RC Leiden, The Netherlands and ${ }^{5}$ Department of Pediatrics, VU University Medical Center, PO Box 7057, MB \\ Amsterdam, The Netherlands \\ (Correspondence should be addressed to F W Dekker; Email: f.w.dekker@lumc.nl)
}

\begin{abstract}
Background: The long-term effects of perinatal growth and corticosteroid exposure on adrenal steroid concentrations in adults born very preterm are uncertain.

Objectives: To examine the effect of birth weight, early postnatal growth, and pre- and postnatal corticosteroid administration on serum adrenal steroids in 19-year-old subjects born very preterm. Design and methods: Subjects born before 32 weeks of gestation in The Netherlands participating in the Project on Preterm and Small for Gestational Age Infants (POPS) were investigated at 19 years of age. Serum cortisol, DHEA sulfate (DHEAS), and androstenedione (Adione) concentrations were measured in 393 out of 676 eligible subjects, compared with controls, and associated with perinatal growth and pre- and postnatal corticosteroids administration using multiple linear regression analyses.

Results: Serum DHEAS and Adione in men and women were higher than in controls. In the multiple regression analyses, birth weight SDS showed a statistically significant negative association with serum DHEAS concentrations in women $(\beta$ : $-0.865,95 \%$ confidence interval $(\mathrm{CI}):-1.254$ to $-0.476)$ and in men $(\beta$ : $-0.758,95 \%$ CI: -1.247 to -0.268$)$ and with serum Adione concentrations in women $(\beta$ : $-0.337,95 \%$ CI: -0.593 to -0.082$)$. Early postnatal weight gain showed no association with any of measured adrenal markers. In women, serum Adione was associated with postnatal dexamethasone exposure ( $\beta$ : 0.932, 95\% CI: $0.022-1.843)$.

Conclusions: Young adults born very preterm show elevated adrenal androgens, particularly when born small for gestational age. Postnatal corticosteroid administration is positively associated with serum Adione in young women.
\end{abstract}

European Journal of Endocrinology 163 681-689

\section{Introduction}

According to the hypothesis now called 'Developmental origins of health and disease', intrauterine growth retardation, and as a consequence low birth weight for gestational age as well as fast postnatal catch-up growth predisposes to raised blood pressure, cardiovascular disease, type 2 diabetes mellitus, and insulin resistance in adulthood $(1,2)$. A recent meta-analysis suggests that elevated cortisol concentrations may explain part of this association, at least in individuals born at term (3).

Moreover, for the adrenal steroids DHEA sulfate (DHEAS) and androstenedione (Adione), there are indications that intrauterine growth retardation is associated with long-term changes in adult serum concentrations. Various studies have shown that low birth weight is associated with higher serum DHEAS concentrations, and as a consequence predisposes to an earlier adrenarche and/or an adrenal hyperandrogenic profile in adult life (4-7), though in other studies, no such association was observed (8, 9). An early adrenarche appears to be associated with a higher risk of hyperandrogenism and polycystic ovaries $(10,11)$. Furthermore, associations have been found between early postnatal growth and adrenal function in later life (12). In the only study including young adults born preterm ( $<32$ weeks), serum cortisol concentrations in both genders and DHEA, DHEAS, and Adione in women were elevated as compared with control subjects, the latter three being positively correlated with insulin concentrations (7).

Mothers with premature contractions are frequently treated, if time permits, with corticosteroids to stimulate fetal lung maturation (13), and occasionally, very preterm infants need corticosteroids to wean them from mechanical ventilation (14). It is unclear what the long-term consequence are of these therapeutic interventions. In experimental animal studies, corticosteroid administration during the last week of pregnancy 
induces permanent alterations in glucocorticoid activity in the rat and eventually leads to hypertension (15). In young human infants, a brief period of steroid exposure in the first weeks after birth resulted in a mild transient adrenal suppression $(16,17)$. In another study, cortisol concentrations were higher in individuals exposed to betamethasone prenatally compared with nonexposed subjects at 30 years of age. However, this difference disappeared after adjustment for confounding factors (18). The long-term effects of postnatal corticosteroid administration are unknown.

Since the long-term effects of preterm extrauterine growth retardation appear to be similar to those of intrauterine growth retardation (19), we hypothesized that prenatal and early postnatal growth and perinatal corticosteroid administration may affect serum adrenal steroid concentrations in early adulthood in individuals born very preterm. We tested this in 19-year-old participants of the Project on Preterm and Small for Gestational Age Infants (POPS).

\section{Subjects and methods}

\section{Subjects}

The POPS is a nationwide multicenter study on a birth cohort, comprising $94 \%$ of the very preterm $(<32$ weeks of gestation) and/or very low birth weight infants $(<1500 \mathrm{~g})$ born alive in the Netherlands in 1983. In 2002, all eligible subjects aged 19 years were approached by mail to participate in the POPS-19 study for which the approval of the medical ethics committees of all participating centers was obtained. For this study, only those subjects with a gestational age $<32$ weeks were studied. Subjects with congenital malformations leading to changes in body proportions and body composition were not eligible for inclusion, nor subjects who used medication that could influence serum steroid concentrations.

Subjects who gave written informed consent to participate and met the inclusion criteria were seen after an overnight fast between 0830 and $1000 \mathrm{~h}$ at one of the outpatient clinics of the ten participating centers. After a medical history and physical examination, a venous blood sample was obtained after $30 \mathrm{~min}$ in a supine position. Assessors were blinded with respect to perinatal characteristics and perinatal corticosteroid exposure of all subjects.

The findings on growth (20) and cognitive status (21), as well as differences between participating and nonparticipating subjects (22) have been reported previously. Gestational age was assessed by the mother's last day of menstruation. Details about birth characteristics, growth, and other characteristics have been collected from birth onward, and growth and insulin resistance at 19 years were reported previously $(2,20)$. Birth size was expressed as SDS for gestational age and gender using Swedish references (23), and postnatal growth parameters were expressed as SDS for age and gender using Dutch references $(24,25)$. Early postnatal weight gain (EPWG) was defined as the difference between weight SDS at 3 months (corrected for gestational age) and weight SDS at birth ( $\triangle$ SDS). This parameter was the result of an initial period of growth retardation in most cases, followed by a variable degree of catch-up growth. Apgar scores, determined 5 min after birth, were categorized as high $(\geq 6)$ or low $(<6)$.

In 1983, there was no firm scientific basis for administering antenatal betamethasone, and its use was not generally adopted. In practice, some obstetricians refrained from prescribing glucocorticoids prenatally, while others were used to prescribe them on a more regular basis (26). Thus, some pregnant women with impending preterm delivery were treated with two doses of $12 \mathrm{mg}$ betamethasone, given $12 \mathrm{~h}$ apart, prior to birth to accelerate fetal lung maturation, while others did not receive corticosteroids. Inferentially, the allocation of prenatal betamethasone to participants of the POPS study was neither based on maternal nor based on fetal characteristics, but only on different general attitudes toward this form of treatment in the various health centers. The same situation applied to the use of corticosteroids administered postnatally.

To obtain reference values, serum DHEAS and Adione were determined with the same assay in serum samples from 80 healthy volunteers (40 women and 40 men) aged between 18 and 25 years participating as healthy controls in two studies from the Genealogical Department (courtesy of Prof. F Helmerhorst) and the Centre for Human Drug Research (courtesy of Dr J Burggraaf). As cortisol values in the morning are largely dependent on variables as stress, time of awakening, and use of oral contraceptives (OAC), comparison with general reference values is of limited value and is not studied in this group.

\section{Analytical methods}

All blood samples were stored at $-80{ }^{\circ} \mathrm{C}$ and thawed only once immediately before analysis. Cortisol was measured with a fluorescence polarization immunoassay on an Abbott TDx (Abbott Laboratories). The sensitivity of this assay is $20 \mathrm{nmol} / \mathrm{l}$, and the interassay coefficient of variation (CV) ranged from 3.1 to $6.4 \%$ at different concentrations.

DHEAS was measured using a luminescence immunoassay on an Immulite 2500 analyser (Siemens Diagnostics, Breda, the Netherlands). Variation coefficients ranged from 4.3 to $9.6 \%$ over a concentration range of 1.1-7.8 $\mu \mathrm{mol} / \mathrm{l}$. Adione was measured using a RIA of Diagnostic Systems Laboratories (DSL 4200, Beckman Company, Sinsheim, Germany). $\mathrm{CV}$ approximated $10 \%$ over the clinical range of $3-20 \mathrm{nmol} / \mathrm{l}$. 
Insulin (mU/l) and glucose (mmol/l) were measured, and homeostasis model assessment-insulin resistance (HOMA-IR) was calculated as (glucose $\times$ insulin)/22.5 (2).

\section{Statistical analysis}

Statistical analyses were performed in SPSS version 16.0 (SPSS Inc., Chicago, IL, USA). Sex differences were calculated using a Student's $t$-test and a Mann-Whitney $U$ test for normally and nonnormally distributed variables respectively and a $\chi^{2}$-test for the dichotomous variables. Multivariate linear regression analyses were used to obtain regression coefficients. For all tests, a 95\% confidence interval not including zero was considered statistically significant. Multiple pregnancy and socioeconomic status (SES) were included as confounders since they were both associated with perinatal characteristics and concentrations of adrenal hormone concentrations in later life $(27,28)$. SES was classified on a six-point scale in which $>2$ was labeled high and $\leq 2$ was labeled low. In addition, center of care was converted to a dummy variable and added to the model as a covariate to adjust for potential confounding caused by center-specific characteristics. Other variables were not included as confounders because of their potential role in the causal pathway between birth weight and serum hormone concentrations at 19 years of age. In the crude analysis of the multiple regression analysis, EPWG was already adjusted for birth weight. In addition, in women, we tested for interaction between phase of the menstrual cycle and use of OAC and the primary determinants (birth weight SDS, EPWG, prenatal betamethasone exposure, and postnatal betamethasone exposure) on hormone concentrations at age 19. As no interaction was present, the use of OAC was added as a binary covariate in all regression analyses for female participants.

In additional regression analyses, we analyzed the effect of serum insulin and C-peptide concentrations and HOMA-IR on serum cortisol, Adione, and DHEAS concentrations. Since the distribution of HOMA-IR, C-peptide, and insulin was not normally distributed, the logarithmic transformed values were included as products in the regression analyses. To investigate to what extent this effect was confounded by the effect of perinatal characteristics, we corrected for all

Table 1 Perinatal characteristics and findings at 19 years of age in POPS-19 subjects.

\begin{tabular}{|c|c|c|c|}
\hline & Men $(n=189)$ & Women $(n=204)$ & $P$ value \\
\hline \multicolumn{4}{|l|}{ Perinatal characteristics ${ }^{a}$} \\
\hline Gestational age (weeks) ${ }^{\mathrm{b}}$ & $29.7(1.5)$ & $29.8(1.5)$ & 0.714 \\
\hline Birth weight $(\mathrm{g})^{\mathrm{b}}$ & $1383(331)$ & $1273(328)$ & 0.001 \\
\hline Birth weight (SDS) ${ }^{b}$ & $-0.03(0.94)$ & $-0.19(1.07)$ & 0.114 \\
\hline Weight at $3 \mathrm{~m}$ post term $(\mathrm{g})^{\mathrm{b}}$ & $5335(940)$ & 4949 (813) & 0.0001 \\
\hline Weight at $3 \mathrm{~m}$ post term (SDS) & $-1.05(1.69)$ & $-0.93(1.25)$ & 0.427 \\
\hline EPWG $(\Delta S D S)^{b, c}$ & $-1.00(1.60)$ & $-0.71(1.07)$ & 0.046 \\
\hline IRDS history ${ }^{\mathrm{d} e \mathrm{e}}$ & $99(52.4)$ & $93(45.6)$ & 0.178 \\
\hline Multiple birth ${ }^{\mathrm{e}}$ & 47 (24.9) & $47(23.0)$ & 0.671 \\
\hline Prenatal betamethasone $e^{\mathrm{e}}$ & $48(25.4)$ & $31(15.2)$ & 0.012 \\
\hline Postnatal dexamethasone ${ }^{e}$ & $16(8.5)$ & $18(8.8)$ & 0.900 \\
\hline Low Apgar score e,f $^{\text {en }}$ & $27(14.3)$ & $18(8.8)$ & 0.117 \\
\hline Caucasian ${ }^{\mathrm{e}}$ & $162(85.7)$ & $181(88.7)$ & 0.371 \\
\hline Low SES ${ }^{e, g}$ & 66 (34.9) & 69 (34.3) & 0.902 \\
\hline \multicolumn{4}{|l|}{ Characteristics at 19 years $^{\text {h }}$} \\
\hline Weight SDS ${ }^{b}$ & $-0.43(1.24)$ & $-0.52(1.41)$ & 0.483 \\
\hline Height SDS ${ }^{b}$ & $-0.59(1.12)$ & $-0.59(1.10)$ & 0.984 \\
\hline BMI $\left(\mathrm{kg} / \mathrm{m}^{2}\right)^{\mathrm{b}, \mathrm{i}}$ & $21.7(3.1)$ & $21.7(3.4)$ & 0.992 \\
\hline Waist circumference (SDS) ${ }^{b}$ & $0.70(0.98)$ & $0.24(1.19)$ & $<0.0001$ \\
\hline Oral contraceptives & & $136(67.0)$ & - \\
\hline Follicular phase $\mathrm{e}^{\mathrm{ej}}$ & & $35(53.8)$ & - \\
\hline Glucose $(\mathrm{mmol} / \mathrm{l})^{\mathrm{b}}$ & $5.19(0.42)$ & $4.81(0.37)$ & $<0.0001$ \\
\hline Insulin $(\mathrm{mU} / \mathrm{l})^{\mathrm{k}}$ & $8.0(6.0-11.0)$ & $9.0(7.0-11.0)$ & 0.490 \\
\hline C-peptide $(\mathrm{mmol} / \mathrm{l})^{\mathrm{k}}$ & $0.62(0.50-0.80)$ & $0.66(0.55-0.81)$ & 0.068 \\
\hline HOMA-IR ${ }^{\mathrm{k}}$ & $1.92(1.42-2.70)$ & $1.84(1.39-2.49)$ & 0.273 \\
\hline
\end{tabular}

\footnotetext{
aSome characteristics were not measured in a maximum of 28 participants.

${ }^{\mathrm{b}}$ Mean (S.D.) differences were tested by means of an unpaired $t$-test.

'EPWG, early postnatal weight gain was defined by weight SDS at 3 months post term minus weight SDS at birth.

dIRDS, infant respiratory distress syndrome.

${ }^{\mathrm{e}}$ Categorical variable, $n(\%)$, differences were tested by means of a $\chi^{2}$-test.

fLow Apgar score after 5 min was defined by a score $<6$.

${ }^{9}$ SES, socioeconomic status was classified on a six-point scale in which $>2$ was high and $\leq 2$ was low.

${ }^{\mathrm{h}}$ Some characteristics were not measured in a maximum of eight participants.

iBMI, body mass index was calculated as weight divided by squared height $\left(\mathrm{m}^{2}\right)$.

jPart of women not using oral contraceptives who were in the follicular phase of the menstrual cycle.

${ }^{\mathrm{k}}$ Median (IQR) differences were tested by means of a Mann-Whitney $U$ test.
} 
aforementioned perinatal variables in a multivariate variant of these models.

Separate regression analyses were performed to test for interaction between birth weight SDS and EPWG and for interaction between corticosteroid exposure prenatally and postnatally. In these two models, we included the product of birth weight SDS and EPWG and the product of prenatal betamethasone and postnatal dexamethasone administration respectively as an interaction term.

\section{Results}

In 1983, 1012 individuals in the POPS cohort were born at $<32$ weeks of gestation. Before the age of 19 years, 336 subjects died. Consequently, 676 individuals were eligible for this study, of which 178 individuals were lost to follow-up (response rate $73.7 \%$ ). In 105 participants, no laboratory analyses could be performed, resulting in a total of 393 individuals who were included in the statistical analyses in this study. Comparing the study group with the subjects who did not participate in the follow-up study $(n=178)$ revealed that male sex, lower SES, non-Caucasian origin, and a higher morbidity were independently associated with nonresponse. Birth weight SDS, gestational age, and perinatal corticosteroid administration were not significantly different between the response group and nonresponse group (data not shown). The 105 subjects from whom no blood could be withdrawn were not significantly different with respect to the baseline parameters from those included in the current analysis. None of the subjects reported hirsutism, and none used medication that could affect serum prolactin concentrations. Two subjects used L-thyroxine treatment for hypothyroidism.

For the reference group in which Adione and DHEAS concentrations were determined, mean (s.D.) age was 19.5 (1.0), 21.8 (1.4), and 21.8 (2.0) years for women using $\mathrm{OAC}$, women not using $\mathrm{OAC}$, and men respectively.
Table 1 shows characteristics of the subjects in the perinatal phase and at follow-up. Mean gestational age was $\sim 30$ weeks. Mean birth weight was close to $1300 \mathrm{~g}$, slightly higher in men than in women, but when expressed as SDS, mean birth weight was equal in both genders (close to -0.1 SDS). Weight at 3 months post term was $\sim-1$ SDS, with EPWG being more compromised in men than in women. Prenatal betamethasone administration was more frequent in men than in women. At 19 years of age, height and weight SDS were similar in women and men, and lower compared to population references. Waist circumference was higher in men, and was higher in both genders than in the general population, as earlier reported (19). Mean fasting glucose concentrations were higher in males than in females, but median insulin, C-peptide, and HOMA-IR were similar in both genders.

In Table 2, serum cortisol, DHEAS, and Adione are shown for men and women (with or without OAC) in POPS subjects and healthy controls. The use of OAC is associated with a considerable increase in cortisol concentrations, and a decrease in DHEAS and Adione. In women not using OAC, serum hormone concentrations did not differ significantly between individuals in follicular or luteal phase of the menstrual cycle (data not shown). After excluding women using OAC, serum cortisol was not different between genders. Serum DHEAS concentrations were lower in women without OAC than in men in POPS subjects, and even lower in women using OAC. In all three groups, DHEAS was higher in POPS subjects compared to controls. Adione was highest in women not using OAC, followed by men and women using OAC. Adione in POPS men was significantly higher than controls, and in POPS women without OAC, it was significantly lower.

In Tables 3-5, results of the multiple regression analyses for serum cortisol, DHEAS, and Adione versus early growth and perinatal corticosteroid exposure are presented. For cortisol (Table 3), no association was observed between serum concentrations and birth weight, EPWG, and perinatal corticosteroid administration. For DHEAS (Table 4), in both men and women,

Table 2 Serum hormone levels within subgroups of POPS subjects at 19 years of age.

\begin{tabular}{|c|c|c|c|c|c|c|}
\hline & \multicolumn{2}{|c|}{ Men } & \multicolumn{4}{|c|}{ Women } \\
\hline & $\begin{array}{c}\text { POPS } \\
(n=189)^{\mathrm{a}}\end{array}$ & $\begin{array}{c}\text { Reference } \\
(n=40)\end{array}$ & \multicolumn{2}{|c|}{ Oral contraceptives } & \multicolumn{2}{|c|}{ No oral contraceptives } \\
\hline Cortisol $(\mu \mathrm{mol} / \mathrm{l})^{\mathrm{b}}$ & $0.40(0.11)$ & & $0.90(0.29)$ & & $0.37(0.14)$ & \\
\hline DHEAS $(\mu \mathrm{mol} / \mathrm{l})^{\mathrm{b}}$ & $9.33(3.21)^{*}$ & 7.65 (2.95) & $5.80(2.56)^{*}$ & $4.44(2.18)$ & $8.42(3.61)^{*}$ & $6.37(2.37)$ \\
\hline Androstenedione $(\mathrm{nmol} / \mathrm{l})^{\mathrm{b}}$ & $5.31(1.56)^{*}$ & $4.69(1.54)$ & $4.60(1.77)$ & $5.22(2.19)$ & $6.21(2.08)^{*}$ & $7.27(1.98)$ \\
\hline
\end{tabular}

${ }^{*}$ Statistically significant difference between POPS subjects and reference subjects $(P<0.05)$.

${ }^{a}$ Not available in a maximum of four subjects.

${ }^{\mathrm{b}}$ Serum hormone concentrations are presented as mean (S.D.), and differences between POPS individuals and reference subjects were tested by an unpaired $t$-test. 
Table 3 Multiple regression analysis for serum cortisol levels.

\begin{tabular}{|c|c|c|c|c|}
\hline & \multicolumn{2}{|c|}{ Women $(n=204)^{a}$} & \multicolumn{2}{|c|}{$\operatorname{Men}(n=189)^{\mathrm{a}}$} \\
\hline & Crude $\beta(95 \% \mathrm{Cl})^{\mathrm{b}}$ & Adjusted $\beta(95 \% \mathrm{Cl})^{\mathrm{C}}$ & Crude $\beta(95 \% \mathrm{Cl})$ & Adjusted $\beta(95 \% \mathrm{Cl})^{\mathrm{C}}$ \\
\hline $\begin{array}{l}\text { Birth weight }(\text { SDS }) \\
\text { EPWG }(\Delta S D S)^{d} \\
\text { Prenatal beta }^{\mathrm{e}} \\
\text { Postnatal dexa }^{\mathrm{f}}\end{array}$ & $\begin{array}{r}-0.003(-0.037 \text { to } 0.031) \\
0.023(-0.012 \text { to } 0.058) \\
-0.001(-0.098 \text { to } 0.099) \\
-0.004(-0.127 \text { to } 0.118)\end{array}$ & $\begin{array}{r}-0.005(-0.041 \text { to } 0.031) \\
0.035(-0.002 \text { to } 0.072) \\
0.001(-0.098 \text { to } 0.099) \\
-0.010(-0.135 \text { to } 0.114)\end{array}$ & $\begin{array}{r}0.000(-0.018 \text { to } 0.017) \\
-0.002(-0.012 \text { to } 0.009) \\
-0.024(-0.061 \text { to } 0.013) \\
0.055(-0.003 \text { to } 0.113)\end{array}$ & $\begin{array}{r}-0.000(-0.019 \text { to } 0.018) \\
-0.000(-0.012 \text { to } 0.010) \\
-0.042(-0.084 \text { to } 0.000) \\
0.054(-0.008 \text { to } 0.117)\end{array}$ \\
\hline
\end{tabular}

${ }^{\text {aS }}$ Some characteristics were measured in a slightly fewer participants.

${ }^{\mathrm{b}}$ The crude analysis for women was also adjusted for the use of oral contraceptives.

${ }^{\mathrm{c}}$ Adjusted for gestational age, SES, multiple pregnancy, center of care, and use of oral contraceptives in women.

dEPWG, early postnatal weight gain was defined by weight SDS at 3 months minus birth weight SDS. In the crude analysis, EPWG was already corrected for birth weight SDS.

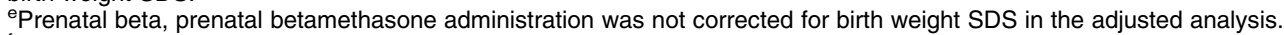

${ }^{f}$ Postnatal dexa, postnatal dexamethasone administration was also corrected for prenatal betamethasone administration and birth weight SDS.

a statistically significant inverse association was found with birth weight, persisting after adjustment for confounders. EPWG, prenatal betamethasone administration, and postnatal dexamethasone administration showed no association with serum DHEAS concentrations at 19 years of age in both men and women. Concerning serum Adione concentrations (Table 5), birth weight showed a statistically significant negative association in women and a negative trend in men. In women, prenatal betamethasone administration after adjustment and postnatal dexamethasone administration were positively correlated with serum Adione concentrations. In men, no trend was observed between perinatal corticosteroid exposure and serum Adione concentrations at 19 years of age. Testing for interaction between birth weight SDS and EPWG and for interaction between corticosteroid exposure prenatally and postnatally in association with adrenal hormone concentrations did not alter our findings substantially (data not shown). Moreover, adjustment for waist circumference did not significantly change the results found (data not shown).

In Table 6, the associations between serum insulin and C-peptide concentrations and HOMA-IR versus serum DHEAS are shown. In women not using OAC, a positive trend was observed with DHEAS, but after adjustment for perinatal characteristics, betas became close to zero. Concerning cortisol and Adione, point estimates were centered around zero and were nonsignificant for both male and female POPS subjects (data not shown).

\section{Discussion}

In this prospective study in young adults born very preterm, serum DHEAS concentrations were increased as compared with controls and negatively associated with birth weight in both genders. Serum Adione concentrations in men were increased but not associated with perinatal corticosteroid exposure, while in women, they were decreased and positively associated with perinatal corticosteroid exposure. In both genders, Adione was negatively associated with birth weight SDS. Serum cortisol did not show any association with early growth nor corticosteroid exposure. EPWG (weight SDS 3 months post term minus birth weight SDS) was not associated with any of the measured adrenal hormones. In women not using OAC, the association between insulin, C-peptide, and HOMA-IR versus DHEAS showed a positive trend, which disappeared after adjustment for perinatal characteristics.

The increased DHEAS concentrations in very preterm born young adults, in combination with the negative

Table 4 Multiple regression analysis for serum DHEA sulfate levels.

\begin{tabular}{|c|c|c|c|c|}
\hline & \multicolumn{2}{|c|}{ Women $(n=200)^{\mathrm{a}}$} & \multicolumn{2}{|c|}{$\operatorname{Men}(n=185)^{\mathrm{a}}$} \\
\hline & Crude $\beta(95 \% \mathrm{Cl})^{\mathrm{b}}$ & Adjusted $\beta(95 \% \mathrm{Cl})^{\mathrm{C}}$ & Crude $\beta(95 \% \mathrm{Cl})$ & Adjusted $\beta(95 \% \mathrm{Cl})^{\mathrm{C}}$ \\
\hline Birth weight (SDS) & $-0.865(-1.254$ to -0.476$)$ & $-0.889(-1.298$ to -0.481$)$ & $-0.758(-1.247$ to -0.268$)$ & $-0.799(-1.320$ to -0.277$)$ \\
\hline EPWG $(\Delta S D S)^{d}$ & $0.289(-0.114$ to 0.692$)$ & $0.378(-0.052$ to 0.808$)$ & $0.058(-0.249$ to 0.364$)$ & $-0.005(-0.346$ to 0.336$)$ \\
\hline Prenatal beta ${ }^{e}$ & $0.699(-0.471$ to 1.870$)$ & $1.000(-0.191$ to 2.191$)$ & $-0.212(-1.283$ to 0.859$)$ & $-0.050(-1.148$ to 1.249$)$ \\
\hline Postnatal dexa ${ }^{f}$ & $-0.418(-1.860$ to 1.024$)$ & $-0.375(-1.798$ to 1.047$)$ & $-0.799(-2.504$ to 0.906$)$ & $-0.142(-1.925$ to 1.642$)$ \\
\hline
\end{tabular}

${ }^{a}$ Some characteristics were measured in a slightly fewer participants.

bThe crude analysis for women was also adjusted for the use of oral contraceptives.

${ }^{\mathrm{c}}$ Adjusted for gestational age, SES, multiple pregnancy, center of care, and use of oral contraceptives in women.

${ }^{d}$ EPWG, early postnatal weight gain was defined by weight SDS at 3 months minus birth weight SDS. In the crude analysis, EPWG was already corrected for birth weight SDS.

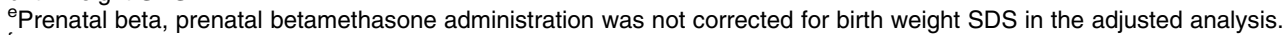

${ }^{f}$ Postnatal dexa, postnatal dexamethasone administration was also corrected for prenatal betamethasone administration and birth weight SDS. 
Table 5 Multiple regression analysis for serum androstenedione levels.

\begin{tabular}{|c|c|c|c|c|}
\hline & \multicolumn{2}{|c|}{ Women $(n=200)^{\mathrm{a}}$} & \multicolumn{2}{|c|}{$\operatorname{Men}(n=185)^{\mathrm{a}}$} \\
\hline & Crude $\beta(95 \% \mathrm{Cl})^{\mathrm{b}}$ & Adjusted $\beta(95 \% \mathrm{Cl})^{\mathrm{C}}$ & Crude $\beta(95 \% \mathrm{Cl})$ & Adjusted $\beta(95 \% \mathrm{Cl})^{\mathrm{c}}$ \\
\hline Birth weight (SDS) & $-0.337(-0.593$ to -0.082$)$ & $-0.266(-0.531$ to -0.002$)$ & $-0.200(-0.442$ to 0.042$)$ & $-0.171(-0.430$ to 0.088$)$ \\
\hline EPWG $(\Delta S D S)^{d}$ & $0.144(-0.121$ to 0.408$)$ & $0.129(-0.153$ to 0.412$)$ & $0.017(-0.131$ to 0.165$)$ & $0.067(-0.100$ to 0.234$)$ \\
\hline Prenatal beta ${ }^{e}$ & $0.580(-0.165$ to 1.324$)$ & $0.856(0.118$ to 1.594$)$ & $-0.376(-0.894$ to 0.142$)$ & $-0.408(-0.988$ to 0.173$)$ \\
\hline Postnatal dexa ${ }^{f}$ & $0.932(0.022$ to 1.843$)$ & $1.318(0.421$ to 2.214$)$ & $0.177(-0.653$ to 1.008$)$ & $0.381(-0.500$ to 1.262$)$ \\
\hline
\end{tabular}

aSome characteristics were measured in a slightly fewer participants.

${ }^{\mathrm{b}}$ The crude analysis for women was also adjusted for the use of oral contraceptives.

${ }^{c}$ Adjusted for gestational age, SES, multiple pregnancy, center of care, and use of oral contraceptives in women

${ }^{d}$ EPWG, early postnatal weight gain was defined by weight SDS at 3 months minus birth weight SDS. In the crude analysis, EPWG was already corrected for birth weight SDS.

ePrenatal beta, prenatal betamethasone administration was not corrected for birth weight SDS in the adjusted analysis.

${ }^{f}$ Postnatal dexa, postnatal dexamethasone administration was also corrected for prenatal betamethasone administration and birth weight SDS

association with birth weight SDS in the POPS subjects, suggest that intrauterine growth of very preterm born individuals affects serum DHEAS concentrations. Our results concerning DHEAS are similar to those of the only previous study in individuals born under 32 weeks of gestation (7). However, since in that study birth weight was not corrected for gestational age, it is likely that the association between birth weight and serum concentrations is, at least partly, confounded by gestational age. The results of our study and the previous study in very preterm born subjects are supported by several studies in individuals born $>32$ weeks of gestation $(4-6,12,29-31)$, suggesting that programming of the hypothalamic-pituitary-adrenal (HPA) axis starts before 32 weeks. This is consistent with the observation that the adrenals are already able to respond to exogenous stimulation with $\mathrm{CRH}$ or ACTH at 26 weeks of gestation $(16,17,32)$. The role of growth retardation on adrenal programming between 32 and 40 weeks could not be investigated in our study, because no weight SDS at term was available.

The crude positive trend between fasting log insulin concentrations, log C-peptide concentrations, and HOMA-IR versus serum DHEAS in women, particularly women not using $\mathrm{OAC}$, is in line with results obtained in the previous study conducted in preterm born individuals (7). However, after adjustment for perinatal characteristics, betas were markedly reduced. We speculate that both insulin resistance and adrenal hyperandrogenism are caused by aberrant perinatal growth in preterms, or that preterm birth causes insulin resistance, which in turn causes overproduction of DHEAS. The latter hypothesis is supported by observations that insulin overall stimulates $\mathrm{P} 450 \mathrm{c} 17 \mathrm{a}$ activity through increased 17-hydroxylase activity, which is only partially compensated by a decreased 17,20-lyase activity (33). A third possibility is that corticosteroid-binding globulin (CBG) may play a role in the elevated DHEAS concentrations (34).

The situation with respect to Adione seems to be more complex, because Adione in women is produced for $\sim 50 \%$ in the adrenals, and the remainder in the ovaries (35). In men, the majority of Adione is produced in the adrenals, and a smaller part in the testes $(35,36)$. Our finding that serum Adione in female participants in POPS is lower than in female controls, in contrast to the elevated DHEAS concentrations, would suggest that gonadal production of Adione may be decreased, or that the conversion of DHEA to Adione is decreased in the adrenal. Interestingly, there was a significant negative association with birth weight SDS, suggesting that the adrenal component may still increase with decreasing birth weight. In men, Adione was elevated in preterm born individuals, and negatively associated with birth weight SDS, although not statistically significant. In the previous study in preterm born individuals (7), Adione was elevated in both genders, but negatively correlated with birth weight only in women. In that study, and consistent with our findings, no association was found with serum insulin

Table 6 Multiple regression analysis for measures of insulin resistance and serum DHEA sulfate (DHEAS) levels, stratified for the use of oral contraceptives (OAC).

\begin{tabular}{|c|c|c|c|c|}
\hline & \multicolumn{2}{|c|}{ Women without oral contraceptives $(n=65)^{\mathrm{a}}$} & \multicolumn{2}{|c|}{ Women with oral contraceptives $(n=134)^{\mathrm{a}}$} \\
\hline & Crude $\beta(95 \% \mathrm{Cl})$ & Adjusted $\beta(95 \% \mathrm{Cl})^{\mathrm{b}}$ & Crude $\beta(95 \% \mathrm{Cl})$ & Adjusted $\beta(95 \% \mathrm{Cl})^{\mathrm{b}}$ \\
\hline IR) & 2.580( & 0 & 0.38 & 85) \\
\hline Log (insulir & $3.092(-1.422$ to 7 & 0.812( & $-0.303(-3)$ & $-0.359(-2$ \\
\hline Log (C-peptide) & $4.223(-2.085$ to 10.531$)$ & $1.211(-5.517$ to 7.938$)$ & $0.559(-2.602$ to 3.719$)$ & $0.645(-2.430$ to 3.721$)$ \\
\hline
\end{tabular}

aOut of the total of 203 women, in 2 subjects not using OAC and in 2 subjects using OAC, serum DHEAS was not measured.

${ }^{b}$ Associations were adjusted for birth weight, gestational age, SES, multiple pregnancy, center of care, use of oral contraceptives in women, prenatal betamethasone administration, and postnatal dexamethasone administration. 
concentrations, although insulin and insulin-like growth factors appear to stimulate the LH-induced androgen production in ovarian theca cells $(37,38)$.

For all steroids, there were differences between men, women without OAC, and women using OAC. Cortisol in women using OAC was much higher than the other groups, which could be attributed to an elevated concentration of CBG induced by estrogens $(39,40)$. The lower DHEAS concentrations in women than in men, and still lower concentrations in women using OAC, can be explained by the increased metabolic clearance induced by estrogens $(41,42)$. This observation is supported by a randomized controlled trial in which introduction of OAC lowered adrenal androgen concentrations substantially (43). The lower Adione concentrations in men as compared with concentrations in women not using OAC can be explained by the lower Adione production in the testes than in the ovaries. The Adione suppression by OAC is due to the suppression of ovarian steroid production by the inhibition of gonadotropins, particularly LH (44).

In association with perinatal corticosteroid exposure in women, only serum Adione concentrations displayed a statistically significant positive association with postnatal dexamethasone administration and (after adjustment) also with prenatal betamethasone administration. The apparent sex difference in the sensitivity to steroid exposure is in line with observations in the rat: the response of the HPA axis in the female rat to stress is much more profound than the response observed in males (45).

A possible limitation of this study is that the substantial number of loss to follow-up (22), which could have introduced bias by nonresponse. However, as birth weight, weight at 3 months, and perinatal corticosteroid administration were not different between responders and nonresponders, confounding is unlikely. Furthermore, because perinatal corticosteroid administration was not randomly assigned, selection bias could have been introduced. However, Vandenbroucke argued that in case of unknown consequences of a therapy modality, allocation of that therapy is independent of these consequences and therefore random (46). Concerning perinatal corticosteroid administration in the 1980s, long-term consequences, and especially the effect on serum adrenal hormone concentrations, were not known (26). Therefore, allocation of corticosteroids in POPS may be considered to be random. Finally, since phenotypic parameters (such as a semiobjective assessment of hirsutism, e.g. a Ferriman-Gallwey score) of adrenal hyperactivity were not recorded in this study, the clinical relevance of the biochemical findings remains uncertain.

In conclusion, adults born very preterm, in particular women with a low birth weight for gestational age or who received corticosteroids perinatally, may be at increased risk of the consequences of adrenal hyperandrogenism.

\section{Declaration of interest}

The authors declare that there is no conflict of interest that could be perceived as prejudicing the impartiality of the research reported.

\section{Funding}

This research did not receive any specific grant from any funding agency in the public, commercial, or not-for-profit sector.

\section{Acknowledgements}

We acknowledge the help of Dr J Burggraaf (Centre for Human Drug Research, Leiden) and Prof. Dr F Helmerhorst (Department of Gynecology, Leiden University medical Center, Leiden) for their help in obtaining control samples. We acknowledge the help of all participants of the Dutch POPS-19 Collaborative Study Group: TNO Quality of Life, Leiden (E T M Hille, C H de Groot, H Kloosterboer-Boerrigter, A L den Ouden, A Rijpstra, S P VerlooveVanhorick, and J A Vogelaar); Emma Children's Hospital AMC, Amsterdam (J H Kok, A Ilsen, M van der Lans, W J C Boelen-van der Loo, T Lundqvist, and H S A Heymans); University Hospital Groningen, Beatrix Children's Hospital, Groningen (E J Duiverman, W B Geven, M L Duiverman, L I Geven, and E J L E Vrijlandt); University Hospital Maastricht, Maastricht (A L M Mulder and A Gerver); University Medical Center St Radboud, Nijmegen (L A A Kollée, L Reijmers, and R Sonnemans); Leiden University Medical Center, Leiden (J M Wit, F W Dekker, and M J J Finken); Erasmus MC-Sophia Children's Hospital, University Medical Center Rotterdam (N Weisglas-Kuperus, M G Keijzer-Veen, A J van der Heijden, and J B van Goudoever); VU University Medical Center, Amsterdam (M M van Weissenbruch, A Cranendonk, H A Delemarre-van de Waal, L de Groot, and J F Samsom); Wilhelmina Children's Hospital, University Medical Center, Utrecht (L S de Vries, K J Rademaker, E Moerman, and M Voogsgeerd); Máxima Medical Center, Veldhoven (M J K de Kleine, P Andriessen, C C M Dielissen van Helvoirt, and I Mohamed); Isala Clinics, Zwolle (H L M van Straaten, W BAdionerts, G W Veneklaas Slots-Kloosterboer, and E M J Tuller-Pikkemaat); Royal Effatha Guyot Group, Zoetermeer (M H Ens-Dokkum); and Association for Parents of Premature Babies, Leidschendam (G J van Steenbrugge).

\section{References}

1 Barker DJ. The developmental origins of adult disease. Journal of the American College of Nutrition 200423 588S-595S.

2 Finken MJ, Keijzer-Veen MG, Dekker FW, Frolich M, Hille ET, Romijn JA \& Wit JM. Preterm birth and later insulin resistance: effects of birth weight and postnatal growth in a population based longitudinal study from birth into adult life. Diabetologia $2006 \mathbf{4 9}$ 478-485. (doi:10.1007/s00125-005-0118-y)

3 van Montfoort N, Finken MJ, le Cessie S, Dekker FW \& Wit JM. Could cortisol explain the association between birth weight and cardiovascular disease in later life? A meta-analysis. European Journal of Endocrinology 2005153 811-817. (doi:10.1530/eje.1. 02050)

4 Dahlgren J, Boguszewski M, Rosberg S \& Bertsson-Wikland K. Adrenal steroid hormones in short children born small for gestational age. Clinical Endocrinology $1998 \quad \mathbf{4 9} \quad 353-361$. (doi:10.1046/j.1365-2265.1998.00514.x)

5 Francois I \& de Zegher F. Adrenarche and fetal growth. Pediatric Research 199741 440-442. (doi:10.1203/00006450-199703 000-00023)

6 Radetti G, Renzullo L, Gottardi E, D’Addato G \& Messner H. Altered thyroid and adrenal function in children born at term and preterm, small for gestational age. Journal of Clinical Endocrinology and Metabolism 200489 6320-6324. (doi:10.1210/jc.2003032185) 
7 Szathmari M, Vasarhelyi B \& Tulassay T. Effect of low birth weight on adrenal steroids and carbohydrate metabolism in early adulthood. Hormone Research 200155 172-178. (doi:10.1159/ $000049991)$

8 Jaquet D, Leger J, Chevenne D, Czernichow P \& Levy-Marchal C. Intrauterine growth retardation predisposes to insulin resistance but not to hyperandrogenism in young women. Journal of Clinical Endocrinology and Metabolism $1999 \mathbf{8 4} 3945-3949$. (doi:10.1210/jc.84.11.3945)

9 Boonstra VH, Mulder PG, de Jong FH \& Hokken-Koelega AC. Serum dehydroepiandrosterone sulfate levels and pubarche in short children born small for gestational age before and during growth hormone treatment. Journal of Clinical Endocrinology and Metabolism 200489 712-717. (doi:10.1210/jc.2003-031160)

10 Ibanez L, Potau N, Marcos MV \& de Zegher F. Exaggerated adrenarche and hyperinsulinism in adolescent girls born small for gestational age. Journal of Clinical Endocrinology and Metabolism 199984 4739-4741. (doi:10.1210/jc.84.12.4739)

11 Ibanez L, Potau N, Marcos MV \& de Zegher F. Adrenal hyperandrogenism in adolescent girls with a history of low birthweight and precocious pubarche. Clinical Endocrinology 2000 53 523-527. (doi:10.1046/j.1365-2265.2000.01133.x)

12 Ong KK, Potau N, Petry CJ, Jones R, Ness AR, Honour JW, de Zegher F, Ibanez L \& Dunger DB. Opposing influences of prenatal and postnatal weight gain on adrenarche in normal boys and girls. Journal of Clinical Endocrinology and Metabolism 200489 2647-2651. (doi:10.1210/jc.2003-031848)

13 Crowther CA \& Harding JE. Repeat doses of prenatal corticosteroids for women at risk of preterm birth for preventing neonatal respiratory disease. Cochrane Database of Systematic Reviews, 2007. CD003935. (doi:10.1002/14651858.CD003935.pub2)

14 Halliday HL, Ehrenkranz RA \& Doyle LW. Early ( $<8$ days) postnatal corticosteroids for preventing chronic lung disease in preterm infants. Cochrane Database of Systematic Reviews, 2010. CD001146. (doi:10.1002/14651858.CD001146.pub3)

15 Levitt NS, Lindsay RS, Holmes MC \& Seckl JR. Dexamethasone in the last week of pregnancy attenuates hippocampal glucocorticoid receptor gene expression and elevates blood pressure in the adult offspring in the rat. Neuroendocrinology $1996 \mathbf{6 4} 412-418$. (doi:10.1159/000127146)

16 Ng PC, Wong GW, Lam CW, Lee CH, Wong MY, Fok TF, Wong W \& Chan DC. Pituitary-adrenal response in preterm very low birth weight infants after treatment with antenatal corticosteroids. Journal of Clinical Endocrinology and Metabolism $1997 \mathbf{8 2}$ 3548-3552. (doi:10.1210/jc.82.11.3548)

17 Ng PC, Wong GW, Lam CW, Lee CH, Fok TF, Wong MY \& Ma KC. Effect of multiple courses of antenatal corticosteroids on pituitaryadrenal function in preterm infants. Archives of Disease in Childhood. Fetal and Neonatal Edition 199980 F213-F216. (doi:10.1136/fn.80.3.F213)

18 Dalziel SR, Walker NK, Parag V, Mantell C, Rea HH, Rodgers A \& Harding JE. Cardiovascular risk factors after antenatal exposure to betamethasone: 30-year follow-up of a randomised controlled trial. Lancet 2005365 1856-1862. (doi:10.1016/S0140-6736 (05)66617-2)

19 Wit JM, Finken MJ, Rijken M \& de Zegher F. Preterm growth restraint: a paradigm that unifies intrauterine growth retardation and preterm extrauterine growth retardation and has implications for the small-for-gestational-age indication in growth hormone therapy. Pediatrics 2006117 e793-e795. (doi:10.1542/peds. 2005-1705)

20 Euser AM, Finken MJ, Keijzer-Veen MG, Hille ET, Wit JM \& Dekker FW. Associations between prenatal and infancy weight gain and BMI, fat mass, and fat distribution in young adulthood: a prospective cohort study in males and females born very preterm. American Journal of Clinical Nutrition 200581 480-487.

21 Hille ET, Weisglas-Kuperus N, van Goudoever JB, Jacobusse GW, Ens-Dokkum MH, de Groot L, Wit JM, Geven WB, Kok JH, de Kleine MJ, Kolle LA, Mulder AL, van Straaten HL, de Vries LS, van Weissenbruch MM, Verloove-Vanhorick SP \& Dutch Collaborative POPS 19 Study Group. Functional outcomes and participation in young adulthood for very preterm and very low birth weight infants: the Dutch Project on Preterm and Small for gestational age infants at 19 years of age. Pediatrics $2007 \mathbf{1 2 0}$ e587-e595. (doi:10.1542/peds.2006-2407)

22 Hille ET, Elbertse L, Gravenhorst JB, Brand R \& VerlooveVanhorick SP. Nonresponse bias in a follow-up study of 19-yearold adolescents born as preterm infants. Pediatrics 2005116 e662-e666. (doi:10.1542/peds.2005-0682)

23 Niklasson A, Ericson A, Fryer JG, Karlberg J, Lawrence C \& Karlberg P. An update of the Swedish reference standards for weight, length and head circumference at birth for given gestational age (1977-1981). Acta Paediatrica Scandinavica 1991 80 756-762. (doi:10.1111/j.1651-2227.1991.tb11945.x)

24 Fredriks AM, van Buuren S, Burgmeijer RJ, Meulmeester JF, Beuker RJ, Brugman E, Roede MJ, Verloove-Vanhorick SP \& Wit JM. Continuing positive secular growth change in The Netherlands 1955-1997. Pediatric Research 200047 316-323. (doi:10.1203/00006450-200003000-00006)

25 Fredriks AM, van Buuren S, Fekkes M, Verloove-Vanhorick SP \& Wit JM. Are age references for waist circumference, hip circumference and waist-hip ratio in Dutch children useful in clinical practice? European Journal of Pediatrics $2005 \mathbf{1 6 4}$ 216-222. (doi:10.1007/s00431-004-1586-7)

26 Keirse MJ. Obstetrical attitudes to glucocorticoid treatment for fetal lung maturation: time for a change? European Journal of Obstetrics, Gynecology, and Reproductive Biology 198417 247-255. (doi:10. 1016/0028-2243(84)90067-4)

27 Li L, Power C, Kelly S, Kirschbaum C \& Hertzman C. Lifetime socio-economic position and cortisol patterns in mid-life. Psychoneuroendocrinology 200732 824-833. (doi:10.1016/j. psyneuen.2007.05.014)

28 Eskola V, Lenko HL \& Tammela O. Impaired adrenocortical function in very low birth weight infants after multiple pregnancies. European Journal of Endocrinology $2003 \mathbf{1 4 9}$ 529-534. (doi:10.1530/eje.0.1490529)

29 Hernandez MI, Martinez A, Capurro T, Pena V, Trejo L, Avila A, Salazar T, Asenjo S, Iniguez G \& Mericq V. Comparison of clinical, ultrasonographic, and biochemical differences at the beginning of puberty in healthy girls born either small for gestational age or appropriate for gestational age: preliminary results. Journal of Clinical Endocrinology and Metabolism 200691 3377-3381. (doi:10.1210/jc.2005-2368)

30 Tenhola S, Martikainen A, Rahiala E, Parviainen M, Halonen P \& Voutilainen R. Increased adrenocortical and adrenomedullary hormonal activity in 12-year-old children born small for gestational age. Journal of Pediatrics $2002 \mathbf{1 4 1} 477-482$. (doi:10.1067/mpd.2002.126923)

31 Ibanez L, Valls C, Potau N, Marcos MV \& de Zegher F. Polycystic ovary syndrome after precocious pubarche: ontogeny of the low-birthweight effect. Clinical Endocrinology 200155 667-672. (doi:10.1046/j.1365-2265.2001.01399.x)

32 Wilson DM, Baldwin RB \& Ariagno RL. A randomized, placebocontrolled trial of effects of dexamethasone on hypothalamicpituitary-adrenal axis in preterm infants. Journal of Pediatrics 1988113 764-768. (doi:10.1016/S0022-3476(88)80398-6)

33 Moghetti P, Castello R, Negri C, Tosi F, Spiazzi GG, Brun E, Balducci R, Toscano V \& Muggeo M. Insulin infusion amplifies 17 alpha-hydroxycorticosteroid intermediates response to adrenocorticotropin in hyperandrogenic women: apparent relative impairment of 17,20-lyase activity. Journal of Clinical Endocrinology and Metabolism 1996 81 881-886. (doi:10.1210/jc.81.3.881)

34 Fernandez-Real JM, Grasa M, Casamitjana R \& Ricart W. The insulin resistance syndrome and the binding capacity of cortisol binding globulin (CBG) in men and women. Clinical Endocrinology 200052 93-99. (doi:10.1046/j.1365-2265.2000.00864.x)

35 Nelson DH. The adrenal cortex: physiological function and disease. Major Problems in Internal Medicine 198018 1-281.

36 Dunn JF, Nisula BC \& Rodbard D. Transport of steroid hormones: binding of 21 endogenous steroids to both testosterone-binding 
globulin and corticosteroid-binding globulin in human plasma. Journal of Clinical Endocrinology and Metabolism 198153 58-68. (doi:10.1210/jcem-53-1-58)

37 Dunaif A, Mandeli J, Fluhr H \& Dobrjansky A. The impact of obesity and chronic hyperinsulinemia on gonadotropin release and gonadal steroid secretion in the polycystic ovary syndrome. Journal of Clinical Endocrinology and Metabolism $1988 \mathbf{6 6}$ 131-139. (doi:10.1210/jcem-66-1-131)

38 Conway GS, Jacobs HS, Holly JM \& Wass JA. Effects of luteinizing hormone, insulin, insulin-like growth factor-I and insulin-like growth factor small binding protein 1 in the polycystic ovary syndrome. Clinical Endocrinology 199033 593-603. (doi:10. 1111/j.1365-2265.1990.tb03897.x)

39 Wiegratz I, Kutschera E, Lee JH, Moore C, Mellinger U, Winkler UH $\&$ Kuhl H. Effect of four different oral contraceptives on various sex hormones and serum-binding globulins. Contraception 200367 25-32. (doi:10.1016/S0010-7824(02)00436-5)

40 Aden U, Jung-Hoffmann C \& Kuhl H. A randomized cross-over study on various hormonal parameters of two triphasic oral contraceptives. Contraception $1998 \mathbf{5 8}$ 75-81. (doi:10.1016/ S0010-7824(98)00071-7)

41 Zumoff BV \& Bradlow HL. Sex difference in the metabolism of dehydroisoandrosterone sulfate. Journal of Clinical Endocrinology and Metabolism 198051 334-336. (doi:10.1210/jcem-51-2-334)

42 Young DG, Skibinski G, Mason JI \& James K. The influence of age and gender on serum dehydroepiandrosterone sulphate (DHEA-S),
IL-6, IL-6 soluble receptor (IL-6 sR) and transforming growth factor beta 1 (TGF-beta1) levels in normal healthy blood donors. Clinical and Experimental Immunology $1999 \mathbf{1 1 7}$ 476-481. (doi:10.1046/j.1365-2249.1999.01003.x)

43 Coenen CM, Thomas CM, Borm GF, Hollanders JM \& Rolland R. Changes in androgens during treatment with four low-dose contraceptives. Contraception 199653 171-176. (doi:10.1016/ 0010-7824(96)00006-6)

44 Moutos D, Smith S \& Zacur H. The effect of monophasic combinations of ethinyl estradiol and norethindrone on gonadotropins, androgens and sex hormone binding globulin: a randomized trial. Contraception 199552 105-109. (doi:10. 1016/S0010-7824(95)00137-9)

45 Handa RJ, Burgess LH, Kerr JE \& O'Keefe JA. Gonadal steroid hormone receptors and sex differences in the hypothalamo-pituitary-adrenal axis. Hormones and Behavior $1994 \mathbf{2 8}$ 464-476. (doi:10.1006/hbeh.1994.1044)

46 Vandenbroucke JP. When are observational studies as credible as randomised trials? Lancet 2004363 1728-1731. (doi:10.1016/ S0140-6736(04)16261-2)

Received 28 July 2010

Accepted 3 August 2010 